\title{
Characterization of Arbuscular Mycorrhizal Spores Isolated from Southern Guinea Savanna of Nigeria
}

\author{
Elizabeth Alori ${ }^{1}$, Oluyemisi Fawole ${ }^{2} \&$ Anthony Afolayan $^{3}$ \\ ${ }^{1}$ Department of Soil Science, Landmark University, P. M. B. 1001, Omu-Aran, Nigeria \\ ${ }^{2}$ Department of Agronomy, University of Ilorin, P.M B. 1515, Ilorin, Nigeria \\ ${ }^{3}$ Department of Botany, University of Fort Hare, Alice 5700, South Africa \\ Correspondence: Elizabeth Alori, Department of Soil Science, Landmark University, P. M. B. 1001, Omu-Aran, \\ Nigeria. Tel: 234-806-348-5837. E-mail: aloritope@yahoo.com
}

Received: January 31, 2012 Accepted: March 5, 2012 Online Published: May 22, 2012

doi:10.5539/jas.v4n7p13 URL: http://dx.doi.org/10.5539/jas.v4n7p13

\begin{abstract}
The hydrolytic activities (cellulases and pectinases) of some arbuscular mycorrhizal fungi (AMF) from four study sites; namely,- Malete, Bacita, Pategi and Ilorin; in southern Guinea savanna of Nigeria were studied. The DNA, RNA and protein contents of their spores were also quantified. Significant differences were observed in the hydrolytic activities of the AMF isolates. Pectinase activity of Malete AMF was F11, $22=192.4$; $(\mathrm{p}<0.05)$; from Ilorin AMF was F13, $26=1.38$; from Bacita AMF was F8, 16 =7.5; while from Pategi AMF was F10, $20=3.64$. On the other hand, cellulase activity of Malete AMF was F11, $22=1.58$; while in Ilorin, it was F $1326=2945.21$; and in Bacita, it was F 8, 16 =3849.34 AMF and in soil from Pategi, F 10, $20=5.681 .23$. Variations in DNA, RNA and protein contents of the 13 isolates were also observed. Scutellospora reticulata was predominant in all the soils; it had the highest hydrolytic activity and highest DNA, RNA and protein contents followed by Glomus pansihalos.
\end{abstract}

Keywords: arbuscular, mycorrhizal fungi, cellulases, pectinases, DNA, RNA, protein

\section{Introduction}

The Arbuscular Mycorrhizal association is one of the active and diverse soil biological communities that are highly essential for increasing the sustainability of agricultural systems. The diversity of AMF has significant ecological consequences because individual species or isolates vary in their potential to promote plant growth and adaptation to biotic and abiotic factors. Thus, the composition and dynamics of populations of AMF have a marked impact on the structure and diversity of the associated plant communities, both in natural and agricultural ecosystems (Gange et al., 1990). The correct identification of individual isolates is essential in the analysis of populations of AMF in ecological studies. Genetic, biochemical and functional analysis of selected isolates are required tools in their characterization. For better nutrient management in southern Guinea savanna of Nigeria, less emphasis on use of chemicals and an increase in the use of biological potential such as AMF is required. In our laboratory, AMF from selected soils of southern Guinea savanna of Nigeria were extracted and their morphological characterization was carried out. Thirteen species of AMF: Scutellospora reticulata, Scutellospora calospora, Scutellospora pellucida, Acalospora laevis, Gigaspora decipien, Gigaspora margarita, Enthrophosphora infrequens, Glomus intraradices, Glomus pansihalos, Glomus tortuosum, Glomus manihotis, Paraglomus brasilianum and Paraglomus occultum were identified in the soil samples (Olowonihi, 2011).

More information, particularly on the biochemical and molecular characteristics of AMF indigenous to soils of this ecological zone is however needed. This paper thus presents the hydrolytic activities as well as DNA, RNA and protein content of the spores of AMF extracted from soils of southern Guinea savannah of Nigeria. Such information would be useful in controlling the AMF symbiosis through agro biotechnology for a sustainable agricultural environment.

\section{Materials and Methods}

\subsection{Collection of Soil Samples}

Soil samples were randomly collected from four locations; Pategi and Bacita soils which are formed over sedimentary rock, Malete and Ilorin soils which are formed over basement complex in southern Guinea savanna of 
Nigeria. Using the random sampling method, auger samples were collected from each of the sampling units at 0-15 $\mathrm{cm}$. The soil samples collected from the four study sites were bulked and transported to the laboratory in well labeled polyethylene bags. The core samples passed through $2 \mathrm{~mm}$ sieve in preparation for analysis haven been air dried for 3 days.

\subsection{Extraction of Arbuscular Mycorrhizal Fungi (AMF) Spores}

AM spores were extracted using the wet- sieving and decanting /density gradient centrifugation method of Brundrett et al. (1996). Enumeration of spores was done under the dissecting microscope with magnification X40. The number of spores per gram of soil was calculated and recorded.

\subsection{Biochemical Characterization of AMF Spores}

Isolates were characterized based on the ability of the spores to produce hydrolytic enzymes - cellulases and pectinases in infected tomato plants.

\subsubsection{Growth of Tomato Plants and Inoculation Procedures}

Tomato (Lycopersicon esculentum) seeds were surface sterilized in $\mathrm{NaCl03}$ for 15 minutes. The surface sterilized seeds were sown in moist filter paper in a petri dish. After 5 days, uniform sized seedlings were transplanted into $300 \mathrm{ml}$ capacity pots filled with grey loam soil. The soil ( $\mathrm{pH} 5.6,2.41 \%$ organic matter, mg kg_1 P NaHCO3 -extractable), was steam sterilized at $100^{\circ} \mathrm{C}$ for $1 \mathrm{hr}$ on each day of 3 consecutive days. The spores of each of the 13 AMF isolated from the selected soils of Southern Guinea Savanna zone of Nigeria were used for the study. Tomato seedlings were inoculated with AMF spores immediately after transplanting them into pots. Inoculation was at the rate of 50 spores per seedling. Plants were kept in a controlled -climate glass house. The tomato Plants were harvested after 40days. The root system that has been washed and rinsed several times with sterile distilled water was used for determination of enzymatic activity.

\subsubsection{Preparation of Extracts for Enzyme Assays}

Roots (10g fresh weight) were pulverized in a mortar with liquid nitrogen and then homogenized in $30 \mathrm{mls}$ of $100 \mathrm{mM}$ tris- $\mathrm{HCl}$ buffer (pH7) plus $0.02 \mathrm{~g}$ polyvinyl- polypyriolidone (PVPP), $10 \mathrm{mM} \mathrm{MgCl} 2,10 \mathrm{mM} \mathrm{NaHCO}$, $10 \mathrm{mM} \beta$ - mercarptoethanol, $0.15 \mathrm{mM}$ phenylmethyl sulphonyl fluoride (PMSF) and $0.3 \% \mathrm{X}$ - 100Triton. Sodium azide $0.03 \%$ was added to the solution. The liquid was then filtered through several layers of cheesecloth and centrifuged at 20,000 rpm for $20 \mathrm{~min}$. The samples were frozen until they were to be used.

\subsubsection{Enzyme Assays}

Using the viscosity reduction method of Rejon- palomare et al. (1996), the extractants were assayed to determine the hydrolytic activities. Carboxymethylcellulose (CMC) and Citrus pectin were used as substrates for cellulases and pectinases respectively. The reduction in viscosity was determined at $0-30 \mathrm{mins}$ intervals.

\subsection{DNA, RNA and Protein Quantification}

Estimation of DNA, RNA and Protein content of AMF spores were carried out at the molecular biology laboratory of the Department of Biochemistry and Microbiology, University of Fort Hare, Alice, South Africa.

\subsubsection{Isolation of Nuclei and Active Chromatin}

To isolate nuclei and active chromatin two hundred AMF spores pulverized in a mortar under liquid nitrogen were used. The suspension washed with buffer containing $10 \mathrm{mM}$ Tris $\mathrm{HCl}, \mathrm{pH} 7.4$, and $150 \mathrm{mM} \mathrm{NaCl}$ was homogenized in a potter-Elvehjem homogenizer with 9 volume of buffer containing $12 \%(\mathrm{w} / \mathrm{v})$ sucrose, $10 \mathrm{mM}$ Tris $\mathrm{HCl}, \mathrm{pH}$ 7.8, $2.5 \mathrm{mM}$ EDTA and $1 \mathrm{mM}$ PMSF. To chelate endogenous $\mathrm{Ca} 2+$ and $\mathrm{Mg} 2+$ EDTA was included in the buffer. The homogenate was filtered through two layers of cheese cloth and centrifuged at $12000 \mathrm{~g}$ for $5 \mathrm{~min}$ over a sucrose cushion [15\% (w/v) sucrose in buffer A (10 mM Tris / HCl, pH 7.8, 10m M NaCl, 1mM PMSF)].

Crude nuclear pellets washed with $12 \%(\mathrm{w} / \mathrm{v})$ sucrose in buffer A, and then twice with Triton X-100 (0.2\%) in buffer A, followed by pelleting over $15 \%(\mathrm{w} / \mathrm{v})$ in buffer A. Pellets were further washed with $12 \%(\mathrm{w} / \mathrm{v})$ sucrose in buffer A to remove traces of Triton X-100. Nuclei were suspended in buffer A (pH 7.0). Nuclei suspended in buffer $\mathrm{A}(\mathrm{pH} 7.0)$ were incubated at $37^{\circ} \mathrm{C}$ for $5 \mathrm{~min}$. EDTA $(2.5 \mathrm{mM}$ final concentration) was added and the solution was placed in ice to stop the reaction. The suspension of nuclei was stirred gently for $15 \mathrm{~min}$ and then centrifuged at $12000 \mathrm{~g}$ for $10 \mathrm{~min}$. The supernatant thus obtained was the active chromatin.

Chromatin was precipitated with $5 \%$ trichloroacetic acid. The pellet obtained on centrifugation $(12000 \mathrm{~g}, 10 \mathrm{~min})$ was washed once with $10 \%$ trichloroacetic acid and then with ethanol. Subsequently the pellet was suspended in $5 \%$ trichloroacetic acid heated at $95^{\circ} \mathrm{C}$. Precipitated proteins were removed by centrifugation $(12000 \mathrm{~g}, 10 \mathrm{~min})$. DNA, RNA and Protein contents were estimated. 


\subsubsection{Estimation of DNA and RNA}

The colorimetric reaction method of orcinol as described by Endo (1970) was used.

\subsubsection{Protein Assay}

Bradford (1976) protein assay method of was used. Dye Stock- Coomassie Blue G (100mg) was dissolved in 50ml of methanol. $100 \mathrm{ml}$ of $85 \%$ H3PO4 was added to the solution which was then diluted to $200 \mathrm{ml}$ with water. The final reagent concentrations were $0.5 \mathrm{mg} / \mathrm{ml} \mathrm{Coomassie} \mathrm{Blue} \mathrm{G,} 25 \%$ methanol, and $42.5 \% \mathrm{H} 3 \mathrm{PO}$. The solution (dark red, $\mathrm{pH} 0.01$ ) was stable in a dark bottle at $4^{0} \mathrm{C}$. One volume of the dye stock was diluted with 4 volumes of distilled water to prepare the assay reagent. A standard curve was made using bovine serum albumin (BSA) with concentrations $0,10,20,3040$ and $50 \mu \mathrm{g} / \mathrm{ml}$. Protein assay procedure- six standard solutions $(1 \mathrm{ml}$ each) containing $0,10,20,30,40$ and $50 \mu \mathrm{g} / \mathrm{ml}$ was prepared. The spectrophotometer was set to collect the spectra at wave length of $575 \mathrm{~nm}$. A $4 \mathrm{ml}$ plastic cuvette filled with distilled water was used to blank the spectrophotometer. $0.8 \mathrm{ml}$ of one of the protein standard was added to $0.2 \mathrm{ml}$ dye stock. This was made up to $4 \mathrm{ml}$ with distilled water and mixed gently. The absorbance spectrum at $575 \mathrm{~nm}$ was recorded. The steps were repeated for each of the protein standard and samples to be assayed.

A graph of absorbance at $575 \mathrm{~nm}$ versus protein for the protein standards was plotted. The protein concentration of samples was then determined from standard curve.

\section{Results and Discussion}

\subsection{Hydrolytic Activities of Isolates}

Some hydrolytic activities of AM fungi isolated from the different study sites are reported in Tables $1 \& 2$. Cellulolytic and pectolytic activities were noted to be significantly higher in AMF inoculated plants than the non inoculated control. Ruiz et al. (2011) also reported differential hydrolytic activities in roots of micropropagated Agave tequilana Weber var. Blue inoculated with Glomus intraradices in comparison with the un- inoculated control. Garmendia et al. (2006) reported hydrolytic activities in pepper roots. infected with Glomus deserticola (Trappe, Bloss and Menge). Garcia- Garrido et al. (1992) also reported endoglucanase activities in extracts from spore and external mycelium of G. mosseae and associated increased hydrolytic activity of the root to AMF infection.

Cellulase, pectinase and xyloglucanase activities have been reported in colonized roots and in external mycelium of AM fungi (Rejon-Palomares et al., 1996). Adriano-Anaya (2006) also reported the the production of cellulases and pectinases by Glomus intraradices both in the root of maize and guinea corn.

In this study, we recorded significant differences in hydrolytic activities of plants infected with varying AMF isolates. This is in agreement with Garcia-Romera et al. (1991), who observed different cellulase and pectinase activities between some Glomus isotypes. The variations in the hydrolytic activities of isolates could be an indication of the AMF isolates belonging to different species and their having varying capacities to colonize host tissues. Scutellospora reticulata infected plants had the highest cellulolytic and pectolytic activities, followed by Glomus pansihalos from the four study sites. The higher hydrolytic enzyme activities of $S$. reticulata and $G$. pansihalos observed, may be a potential mechanism of adaptation of these fungi to colonize plant roots. Garcia-Garrido et al. (2000) reported that the cell-wall degrading enzymes, cellulases, hemicellulases and pectinases are implicated in the penetration of roots by beneficial plant microorganisms such as arbuscular mycorrhizal fungi.

\subsection{DNA, RNA and Protein Content of Spores}

The DNA, RNA and protein content of spores of each isolate differed one from another (Figures 1-3). Ranging from $0.1 \mu \mathrm{g}$ to $0.8 \mu \mathrm{g}$ (DNA), $0.2 \mu \mathrm{g}$ to $1.4 \mu \mathrm{g}$ (RNA) and $1.3 \mu \mathrm{g}$ to $3.5 \mu \mathrm{g}$ (protein content) per 200 spores. Pawlowska, (2005) documented genetic variation within individual and within spore, for ribosomal DNA and protein-coding genes in several species of AMF .According to Parfrey et al. (2008), DNA content varies within individuals throughout life cycles and among individuals within species. Nuclear DNA (nDNA) content determined for two AMF species was reported to be about 0.26 picogram (pg) for Glomus versiforme and 0.75 picogram (pg) for Gigaspora margarita (Bianciotto and Bonfante, 1992). Stommel et al. (2001) reported a mean value of $2 \mu \mathrm{g} / 500$ spores of Gigaspora rosea spores.

Scutellospora. reticulata and Glomus pansihalos had the highest quantities of DNA, RNA and protein in the soils studied as shown in Figures. 1-3. This probably explains the high percentage of their spores in the soil. High levels of DNA correlated with large vegetative cells (Kondorosi et al., 2000). The biochemical and spore based 
characterization in this study has provided a baseline data on the properties of the indigenous AM flora of Southern Guinea savannah zone of Nigeria. This provides a platform for further research work to improve crop production using AM biotechnology.

\section{Acknowledgement}

The authors would like to thank Phytomedicine Research Centre, Botany Department, University of Fort Hare, Alice, 5700, Eastern Cape, South Africa for the opportunity to use their laboratory facilities.

\section{References}

Adriano-Anaya, M. L., Solis-Dominguez, F., Gavito-Pardo, M. E., \& Salvador-Figueroa, M. (2006). Agronomical and environmental factors influence root colonization, sporulation and diversity of arbuscular mycorrhizal fungi at a specific phenological stage of Banana trees. J. Agron., 5(1), 11-15.

Bianciotto, V., \& Bonfante, P. (1992). Quantification of the nuclear DNA content of two arbuscular mycorrhizal fungi. Mycol Res, 96(12), 1071-1076. http://dx.doi.org/10.1016/S0953-7562 (09) 80118-4

Bradford, M. M. (1976). A rapid and sensitive method for the quantitation of microgram quantities of protein utilizing the principle of protein-dye binding. Analytical Biochemistry, 72(1-2), 248-254. http://dx.doi.org/10.1016/0003-2697(76)90527-3

Brundrett, M., Bougher, N., Dell, B., Grove, T., \& Malajczuk, N. (1996). Working with mycorrhizas in forestry and agriculture. Canberra: Australian Centre for international Agricultural Research Monograph, 32, 374.

Endo, Y. (1970). A simultaneous estimation method of DNA and RNA by the orcinol reaction and study on the reaction mechanism. J. Biochem (Tokyo), 67, 629-633.

Gange, A. C., Brown, V. K., \& Farmer, L. M. (1990). A test of mycorrhizal benefit in an early successional plant community. New Phytologist, 115(1), 85- 91. http://dx.doi.org/10.1111/j.1469-8137.1990.tb00925.x

Garcia-Garrido, J. M., Garcia-Romera, I., \& Ocampo, J. A. (1992). Cellulase production by vesicular arbuscular mycorrhizal fungus Glomus mosseae (Nicol and Gerd) Gerd and Trappe. New Phytologist, 121(2), 221-226.

Garcia-Garrido, J. M., Tribak, M., Rejon-Palomare, A., Ocampo, J. A., \& Garcia-Romera, I. (2000). Hydrolitic enzymes and ability of arbuscular mycorrhizal fungi to colonize roots. Journal of experimental Botany, 51(349), 1443-1448. http://dx.doi.org/10.1093/jexbot/51.349.1444

Garcia-Romera, I., Garcia-Garrido, J. M., \& Ocampo, J. A. (1991). Pectinase activity in vesicular- arbuscular mycorrhiza during colonization of lettuce. Symbiosis, 12, 189-198.

Garmendia, I., Aguirreolea, J., \& Goicoechea, N. (2006). Defence-related Enzymes in Pepper Roots During Interactions with Arbuscular Mycorrhizal Fungi and/or Verticillium dahlia. Biocontrol, 55(3), 293-310.

Kondorosi, E., Roudier, F., \& Gendreau, E. (2000). Plant cell-size control: growing by ploi Cuee opin. Plant Biol., 3(6), 488-492. http://dx.doi.org/10.1016/S1369-5266(00)00118-7

Olowonihi, E. T. (2011). Studies on Arbuscular mycorrhizal fungi in selected soils of Southern Guinea Savanna of Nigeria. (Ph.D Thesis), University of Ilorin. Nigeria.

Parfrey, 1. W., Lahr, D. J. G., \& Katz, L. A. (2008). The Dynamic nature of Eukaryotic genomes. Mol. Biol. Evol., 25(4), 787-794. http://dx.doi.org/10.1093/molbev/msn032

Pawlowska, T. E. (2005). Genetic processes inarbuscular mycorrhizal fungi. FEMS Microbiol Lett., 125, 185-192.

Rejon-Palomares, A., Garcia-Garrido, J. M., Ocampo, J. A., \& Garcia-Romera, I. (1996). Presence of xyloglucan-hydrolyzing glucanases (xyloglucanases) in arbuscular mycorrhizal symbiosis. Symbiosis, 21, 249-261.

Ruiz, S., Adriano, L., Ovando, I., Navarro, C., \& Salvador, M. (2011). Biofertilization of micropropagated Agave tequilana: Effect on plant growth and production of hydrolytic enzymes. African Journal of Biotechnology, 10(47), 9623-9630.

Stommel, M., Mann, P., \& Franken P. (2001). Est-library construction using spore RNA of the arbuscular mycorrhizal fungus Gigaspora rosea. Mycorrhiza, 10(6), 281-285. 
Table 1. Production of Cellulase enzyme by AM Fungi

\begin{tabular}{lllll}
\hline & \multicolumn{4}{c}{ Enzyme activity $(\mathbf{U} / \mathbf{m l})$} \\
AMF Species & Ilorin & Malete & Pategi & Bacita \\
\hline P. brasilianum & $6.67 \mathrm{k}$ & $27.24 \mathrm{~g}$ & $6.97 \mathrm{j}$ & - \\
G.intraradices & $24.99 \mathrm{e}$ & - & - & $28.17 \mathrm{e}$ \\
S. reticulata & $59.63 \mathrm{a}$ & $60.57 \mathrm{a}$ & $62.42 \mathrm{a}$ & $55.55 \mathrm{a}$ \\
S.calospora & $6.89 \mathrm{k}$ & $16.37 \mathrm{j}$ & - & - \\
Gi. margarita & $3.54 \mathrm{~m}$ & $18.32 \mathrm{i}$ & $23.12 \mathrm{~g}$ & - \\
E.infrequens & $20.66 \mathrm{f}$ & $34.71 \mathrm{f}$ & $30.18 \mathrm{f}$ & $24.01 \mathrm{f}$ \\
P. occultum & $17.57 \mathrm{~g}$ & - & $40.64 \mathrm{c}$ & $31.03 \mathrm{~d}$ \\
S.pellucida & $37.0 \mathrm{c}$ & $45.42 \mathrm{c}$ & $43.04 \mathrm{~d}$ & $38.6 \mathrm{c}$ \\
A.laevis & $29.42 \mathrm{~d}$ & $37.61 \mathrm{e}$ & $38.68 \mathrm{e}$ & $9.09 \mathrm{~h}$ \\
G.pansihalos & $46.98 \mathrm{~b}$ & $52.50 \mathrm{~b}$ & $54.58 \mathrm{~b}$ & $46.18 \mathrm{~b}$ \\
G.tortuosum & $12.52 \mathrm{i}$ & $8.01 \mathrm{k}$ & $16.44 \mathrm{~h}$ & $15.52 \mathrm{~g}$ \\
G.manihotis & $9.79 \mathrm{j}$ & $42.57 \mathrm{~d}$ & $12.01 \mathrm{i}$ & - \\
Gi.decipien & $13.98 \mathrm{~h}$ & $25.57 \mathrm{~h}$ & - & - \\
No Inoculum & $1.26 \mathrm{n}$ & 1.251 & $1.28 \mathrm{k}$ & $1.27 \mathrm{i}$ \\
Sed & $\mathbf{0 . 4 4 9 5}$ & $\mathbf{0 . 2 0 2 6}$ & $\mathbf{0 . 3 7 1 7}$ & $\mathbf{0 . 3 9 9 3}$ \\
Lsd & $\mathbf{0 . 9 2 3 9}$ & $\mathbf{0 . 4 2 0 2}$ & $\mathbf{0 . 7 7 5 3}$ & $\mathbf{0 . 8 4 6 5}$ \\
\hline
\end{tabular}

Means followed by the same letter along the column are not significantly different at $5 \%$ level of probability using least significant difference (LSD) test.

Table 2. Production of Pectinase enzyme by AM Fungi

\begin{tabular}{lllll}
\hline \multicolumn{1}{c}{ AMF Species } & Ilorin & Malete & Pategi & Bacita \\
\hline P. brasilianum & 26.811 & $37.51 \mathrm{f}$ & $24.58 \mathrm{~g}$ & - \\
G.intraradices & $51.38 \mathrm{e}$ & - & - & $40.3 \mathrm{gh}$ \\
S. reticulata & $96.56 \mathrm{a}$ & $94.22 \mathrm{a}$ & $98.93 \mathrm{a}$ & $95.20 \mathrm{a}$ \\
S.calospora & $33.99 \mathrm{k}$ & $3.74 \mathrm{j}$ & - & - \\
Gi. margarita & $20.47 \mathrm{~m}$ & $3.69 \mathrm{gh}$ & $36.55 \mathrm{f}$ & - \\
E.infrequens & $46.52 \mathrm{f}$ & $62.65 \mathrm{c}$ & $50.91 \mathrm{~d}$ & $60.8 \mathrm{~d}$ \\
P. occultum & $44.66 \mathrm{~g}$ & - & $13.6 \mathrm{~h}$ & $70.3 \mathrm{c}$ \\
S.pellucida & $70.67 \mathrm{c}$ & $16.34 \mathrm{~h}$ & $62.47 \mathrm{c}$ & $59.5 \mathrm{e}$ \\
A.laevis & $55.47 \mathrm{~d}$ & $42.73 \mathrm{e}$ & $44.28 \mathrm{e}$ & $40.80 \mathrm{~g}$ \\
G.pansihalos & $80.00 \mathrm{~b}$ & $77.80 \mathrm{~b}$ & $76.62 \mathrm{~b}$ & $81.00 \mathrm{~b}$ \\
G.tortuosum & $42.74 \mathrm{~h}$ & $9.35 \mathrm{i}$ & - & $42.4 \mathrm{ef}$ \\
G.manihotis & $36.43 \mathrm{j}$ & $51.42 \mathrm{~d}$ & $8.62 \mathrm{j}$ & - \\
Gi.decipien & $42.04 \mathrm{i}$ & $19.01 \mathrm{~g}$ & - & - \\
No Inoculum & $10.58 \mathrm{n}$ & $1.49 \mathrm{j}$ & $1.82 \mathrm{k}$ & $3.40 \mathrm{i}$ \\
Sed & $\mathbf{0 . 2 7 9 0}$ & $\mathbf{3 . 1 1 2}$ & $\mathbf{0 . 2 3 0 3}$ & $\mathbf{1 3 . 9 3}$ \\
Lsd & $\mathbf{0 . 5 7 3 6}$ & $\mathbf{6 . 4 5 4}$ & $\mathbf{0 . 4 8 0 4}$ & $\mathbf{2 9 . 5 2}$ \\
\hline
\end{tabular}

Means followed by the same letter along the column are not significantly different at $5 \%$ level of probability using least significant difference (LSD) test. 


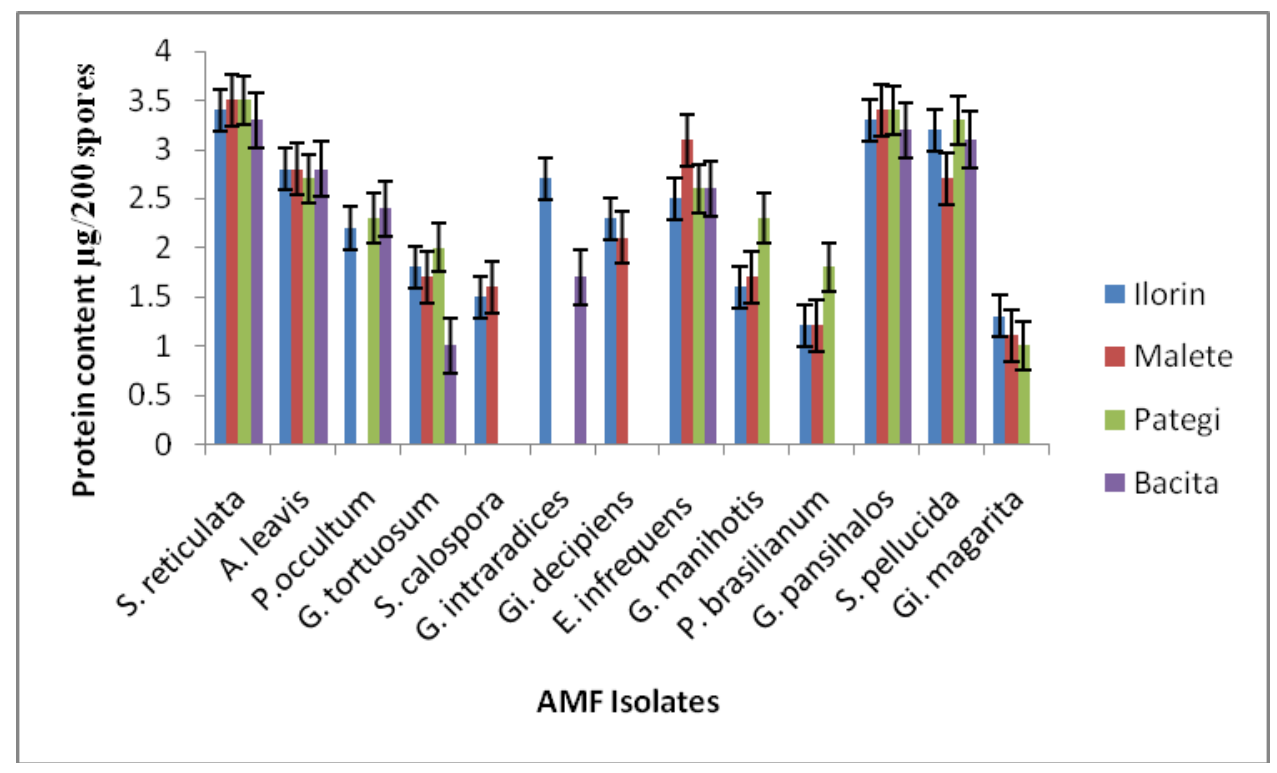

Figure 1. Protein contents of AMF isolates. Bars are standard error

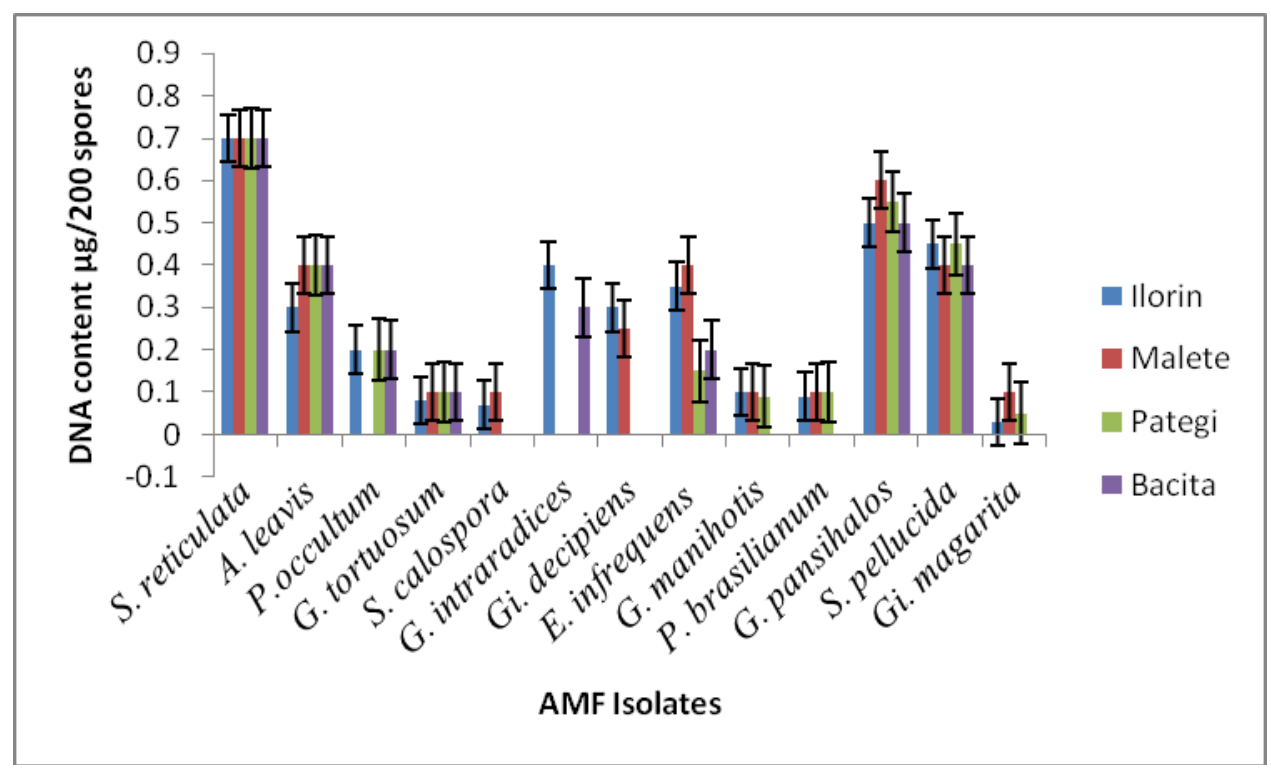

Figure 2. DNA Contents of AMF Isolates. Bars are standard error 


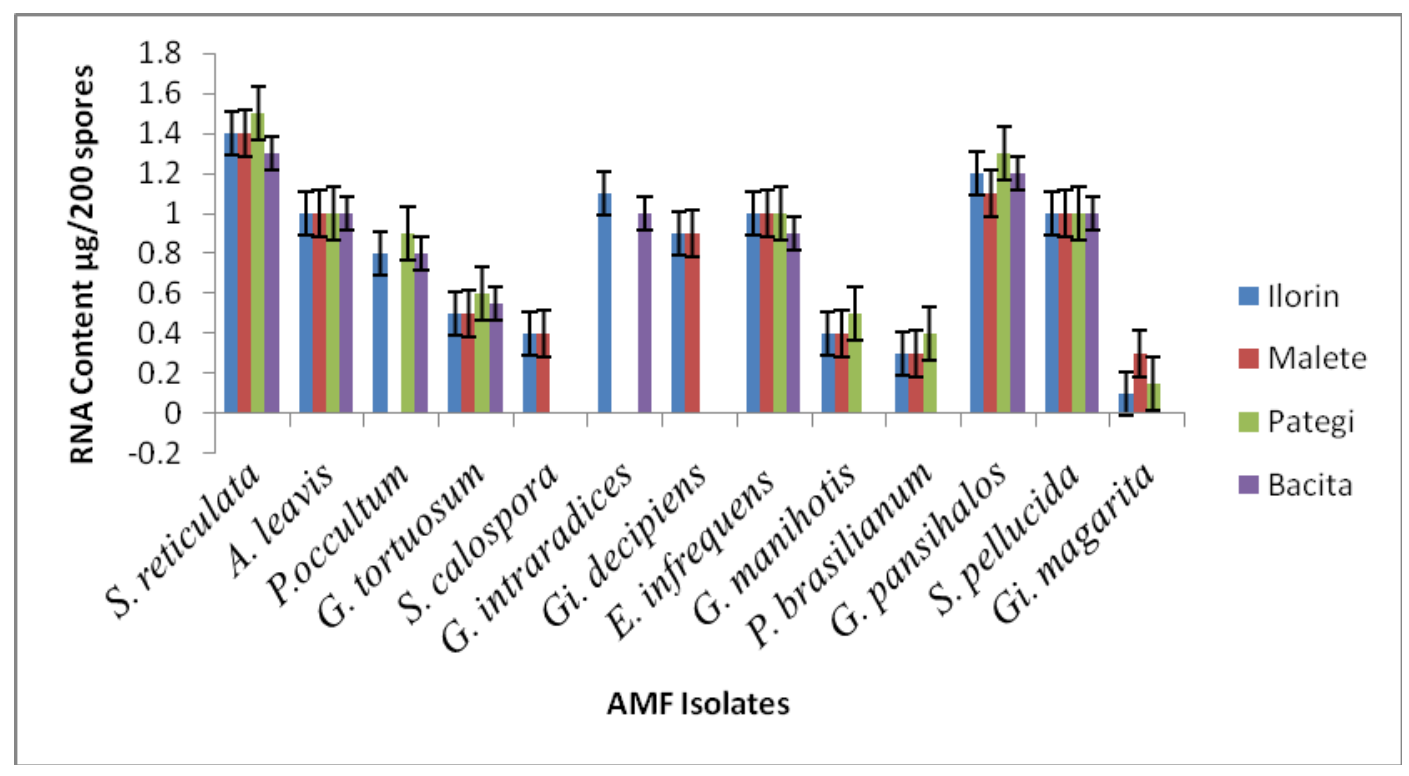

Figure 3. RNA contents of AMF isolates. Bars are standard error 